\title{
PENGARUH GUIDED DISCOVERY LEARNING TERHADAP KEMAMPUAN BERPIKIR KRITIS MATEMATIS SISWA SMPN 6 SINGKAWANG
}

\author{
Anggun Nabela ${ }^{1}$, Mariyam², Nurhayati*3 \\ ${ }^{1,2,3}$ Program Studi Pendidikan Matematika, STKIP Singkawang \\ e-mail: ${ }^{1}$ anggunnabela4@ gmail.com, ${ }^{2}$ mariyam.180488@ gmail.com, \\ nurhayati@stkipsingkawang.ac.id
}

\begin{abstract}
This study aims to determine the effect of the Guided Discovery Learning model on students' mathematical critical thinking skills, student learning activities, and student motivation on the straight line equation VIII SMP Negeri 6 Singkawang. This study used a Quasi Experimental design. The population in this study were all VIII classes of SMP Negeri 6 Singkawang consisting of five classes totaling 160 students. Samples were taken using the Cluster Random Sampling. The data analysis technique used is U-Mann Whitney.The selected sample consists of two classes, namely class VIIIB as the experimental class and class VIIIC as the control class. The results of the analysis show: 1) There is a difference in the ability to think critically mathematically between students who get the Guided Discovery Learning model and students who get conventional learning; 2) Guided Discovery Learning Model gives a high influence on students' mathematical critical thinking skills; 3) Student learning activities are classified as active after the Guided Discovery Learning (GDL) model is applied to the straight line equation VIII grade material at SMPN 6 Singkawang on the ability to think critically mathematically; 4) Students' learning motivation is high with the application of Guided Discovery Learning $(G D L)$ model to the ability to think critically mathematically.
\end{abstract}

Keyword: Guided Discovery Learning Model, mathematical critical thinking skills, student activities, learning motivation.

\begin{abstract}
Abstrak. Penelitian ini bertujuan untuk mengetahui pengaruh model Guided Discovery Learning Terhadap Kemampuan Berpikir Kritis Matematis Siswa, aktivitas belajar siswa, dan motivasi belajar siswa pada materi persamaan garis lurus VIII SMP Negeri 6 Singkawang. Penelitian ini menggunakan desain Quasi Eksperimental.Populasi dalam penelitian ini adalah semua kelas VIII SMP Negeri 6 Singkawang yang terdiri dari lima kelas yang berjumlah 160 siswa. Sampel diambil dengan teknik Cluster Random Sampling. Adapun sampel yang dipilih terdiri dari dua kelas yaitu kelas VIIIB sebagai kelas eksperimen dan kelas VIIIC sebagai kelas kontrol. Tekhnik analisis data yang digunakan adalah U-Mann Whitney. Hasil analisis menunjukkan: 1) Terdapat perbedaan kemampuan berpikir kritis matematis antara siswa yang mendapatkan model Guided Discovery Learning dengan siswa yang mendapatkan pembelajaran konvensional; 2) Model Guided Discovery Learning memberikan pengaruh yang tinggi terhadap kemampuan berpikir kritis matematis siswa; 3) Aktivitas belajar siswa tergolong aktif setelah diterapkan model Guided Discovery Learning (GDL) pada materi persamaan garis lurus kelas VIII SMPN 6 Singkawang terhadap kemampuan berpikir kritis matematis; 4) Motivasi belajar siswa tergolong tinggi dengan diterapkannya model Guided Discovery Learning (GDL) terhadap kemampuan berpikir kritis matematis.
\end{abstract}

Kata Kunci: Model Guided Discovery Learning, kemampuan berpikir kritis matematis, aktivitas siswa, motivasi belajar. 


\section{PENDAHULUAN}

Matematika merupakan salah satu bidang studi yang diajarkan di SMP dan menduduki peranan penting dalam pendidikan. Hal ini dapat dilihat dari waktu jam pelajaran sekolah lebih banyak dibandingkan pelajaran lain. Prihandoko (2006:1) menyatakan bahwa matematika merupakan ilmu dasar yang sudah menjadi alat untuk mempelajari ilmu-ilmu lainnya. Mata pela-jaran matematika perlu diberikan kepada semua peserta didik mulai dari sekolah dasar untuk membekali peserta didik dengan kemampuan berpikir logis, anaᄀlitis, sistematis, kritis, dan kreatif, serta kemampuan bekerjasama.

Pelajaran matematika menghadapkan siswa pada permasalahan yang memerlukan kecermatan dan ketelitian dalam memecahkan suatu persoalan matematika. Untuk memecahkan persoalan matematika tersebut diperlukan kemampuan-kemampuan dasar yang harus dimiliki oleh para siswa agar dapat menghasilkan jawaban-jawaban yang tepat dan kesimpulan yang logis. Kemampuan dasar yang harus dimiliki siswa adalah kemampuan berpikir kritis matematis. Menurut Ennis (1991: 54) dengan berpikir kritis dapat meningkatkan kemampuan berpikir secara rasional dan reflektif yang bertujuan untuk mengambil keputusan tentang apa yang diyakini atau dilakukan. Jadi berpikir kritis adalah proses berpikir yang sistematis yang memungkinkan siswa untuk merumuskan dan memutuskan keyakinannya sendiri serta mengevaluasi setiap keputusannya dengan tepat. Siswa yang memiliki kemampuan berpikir kritis matematis dapat meningkatkan potensi intelektualnya, dan juga rasa percaya diri dalam menyelesaikan persoalan matematika, tidak hanya itu siswa tidak akan takut dan ragu ketika dihadapkan pada masalah nyata dalam kehidupan sehari-hari. Berpikir kritis memungkinkan siswa menganalisis pemikirannya sendiri untuk memastikan bahwa ia telah menentukan pilihan dan menarik kesimpulan yang tepat dan cerdas.

Keterampilan berpikir kritis mate $\neg$ matis sangat penting bagi siswa karena dengan keterampilan ini siswa mampu bersikap rasional dan memilih alternatif pilihan yang terbaik bagi dirinya. Hal ini sejalan dengan penyataan Somakim (2011:43) yang menyatakan bahwa menanamkan kebiasaan berpikir kritis matematis bagi siswa perlu dilakukan agar mereka dapat mencermati berbagai persoalan yang terjadi dalam kehidupan sehari-hari. Pentingnya keterampilan berpikir kritis dan kreatif dilatihkan kepada siswa, didukung oleh visi pendidikan matematika yang mempunyai dua arah pengembangan, yaitu memenuhi kebutuhan masa kini dan masa yang akan datang (Sumarmo, 2002). Visi pertama untuk kebutuhan masa kini, pembelajaran matematika mengarah pada pemahaman konsep-konsep yang diperlukan untuk menyelesaikan masalah matematika dan ilmu pengetahuan lain. Visi kedua untuk kebutuhan masa yang akan datang atau mengarah ke masa depan, mempunyai arti lebih luas, yaitu pembelajaran matematika memberikan 
kemampuan nalar yang logis, sistematis, kritis, dan cermat serta berpikir objektif dan terbuka, yang sangat diperlukan dalam kehidupan sehari-hari. Kemampuan berpikir melatih siswa untuk menyelesaikan masalah matematika dalam menarik kesimpulan serta menggunakan dalam kehidupan sehari-hari.

Jika siswa tidak memiliki kemampuan berpikir kritis, siswa tidak dapat memutuskan untuk dirinya sendiri apa yang harus dipikirkan, apa yang harus dipercaya, dan bagaimana harus bertindak dalam menyelesaikan masalah matematis maupun masalah matematis yang berkaitan dengan kehidupan sehari-hari. Karena gagal berpikir mandiri, maka siswa akan cenderung meniru siswa lain, siswa hanya menerima informasi tanpa memikirkan proses awal, dan menerima kesimpulan dengan pasif. Kemampuan berpikir kritis adalah kemampuan yang penting yang harus dimiliki siswa dalam memecahkan masalah matematis maupun kehidupan sehari-hari, kemampuan berpikir kritis diharapkan dapat dicapai melalui proses belajar mengajar yang baik. Sejalan dengan pendapat Wahyuni, dkk (2018) yang menyatakan bahwa berpikir kritis dapat diartikan sebagai kemampuan menganalisis suatu permasalahan. Maka dapat disimpulkan bahwa kemampuan berpikir kritis matematis adalah suatu kecakapan berpikir secara efektif yang dapat membantu seseorang untuk membuat, mengevaluasi, serta mengambil keputusan tentang apa yang diyakini atau dilakukan.

Namun pada kenyataannya siswa belum menggunakan dan memanfaatkan kemampuan berpikir kritis mereka dengan baik dalam menyelesaikan masalah matematis yang berkaitan dengan soal. Berdasarkan wawancara yang dilakukan dengan guru matematika kelas VIII di SMPN 6 Singkawang rendahnya kemampuan berpikir kritis siswa dikarenakan siswa hanya mencontoh dan tidak dapat mengembangkan kemampuan berpikir kritis matematis mereka. Siswa hanya terpaku pada apa yang diberikan oleh guru tanpa menemukan bagaimana cara penyelesaiannya sendiri. Adanya rasa takut ataupun enggan dalam bertanya kepada guru pada diri siswa sehingga menyebabkan kekeliruan dalam menyelesaikan masalah yang berkaitan dengan soal matematika tersebut.

Kurangnya kemampuan berpikir matematis siswa dinyatakan dalam hasil penelitian Sari, dkk (2016) yang menunjukkan bahwa kemampuan berpikir kritis siswa SMP Negeri 1 Gambut masih tergolong rendah. Berdasarkan analisis data, diperoleh kesimpulan bahwa: (1) Memberikan penjelasan dasar sebesar 46\%; (2) Membangun Keterampilan dasar sebesar 39\%; Menyimpulkan sebesar 14\%; (4) Memberikan penjelasan lanjut sebesar 7\%.

\section{Model Guided Discovery Learning} dirancang untuk mengajarkan konsep dan hubungan antar konsep. Hanafih dan Suhana (dalam Priansa 2015:219) menyatakan bahwa pembelajaran penemuan terbimbing merupakan pelaksanaan penemuan yang dilakukan atas petunjuk dari guru. Pembelajarannya dimulai dari guru mengajukan berbagai pertanyaan yang melacak, dengan tujuan untuk mengarahkan 
peserta didik melakukan percobaan untuk membuktikan pendapat yang dikemukakan.

Dengan menerapkan model Guided

Discovery Learning dapat melatih kemampuan berpikir kritis siswa karena siswa akan lebih memikirkan secara matang bagaimana proses dari suatu penemuan tersebut dan membuat siswa menjadi lebih aktif. Selain itu, berdasarkan penelitian terdahulu terdapat beberapa penelitian yang relevan dengan model Guided Discovery Learning dapat meningkatkan kemampuan berpikir kritis siswa. Berdasarkan hasil penelitian Haris, dkk (2015) dapat disimpulkan bahwa Guided Discovery Learning berpengaruh terhadap kemampuan berpikir kritis siswa dengan hasil nilai kelas eksperimen lebih tinggi dari pada kelas kontrol.

\section{METODE}

Jenis penelitian ini adalah jenis penelitian kuantitatif dengan metode eksperimen. Desain penelitian yang digunakan dalam penelitian ini adalah quasieksperimental design dengan rancangan nonequivalent posttest-only control group design. Terdapat dua kelas dalam penelitian ini yaitu kelas pertama disebut sebagai kelas eksperimen dan kelas kedua disebut sebagai kelas kontrol. Adapun sekolah yang menjadi tempat penelitian adalah di SMP Negeri 6 Singkawang kelas VIII yang beralamat di Jalan Jalan Raya Sedau Kelurahan Sedau Kecamatan Singkawang Selatan. Populasi dalam penelitian ini adalah seluruh kelas VIII SMP Negeri 6 Singkawang yang terdiri dari lima kelas yaitu VIII A, VIII B, VIII C, VIII D dan VIII E yang berjumlah 160 siswa. Teknik pengambilan sampel pada penelitian ini dengan menggunakan teknik cluster random sampling. Adapun yang menjadi kelas eksperimen adalah kelas VIIIB dan kelas kontrol adalah kelas VIIIC.

Teknik analisis data yang digunakan dalam penelitian ini adalah analisis deskriptif dan analisis inferensial. Dalam penelitian ini akan diperoleh data kuantitatif sehingga untuk menganalisis data didapatkan dari pemberian tes hasil belajar, pengamatan menggunakan lembar aktivitas dan motivasi menggunakan lembar angket akan dilakukan teknik statistik.

\section{HASIL DAN PEMBAHASAN}

\section{Kemampuan Berpikir Kritis Matematis} Siswa

Hasil pengumpulan data selama penelitian diperoleh data hasil posttest (berupa skor) dari kelas yang diajarkan dengan model pembelajaran Guided Discovery Learning untuk kelas eksperimen dan pembelajaran langsung untuk kelas kontrol terhadap kemampuan berpikir kritis matematis siswa pada materi persamaan garis lurus. Penilaian kemampuan berpikir kritis matematis siswa dinilai dari skor rata-rata kemampuan berpikir kritis matematis siswa. Adapun soal posttest yang diberikan berbentuk tes kemampuan berpikir kritis sebanyak tiga soal dengan tiga indikator yaitu: (a)Analisis; (b)Eksplanasi; (c)Evaluasi. 


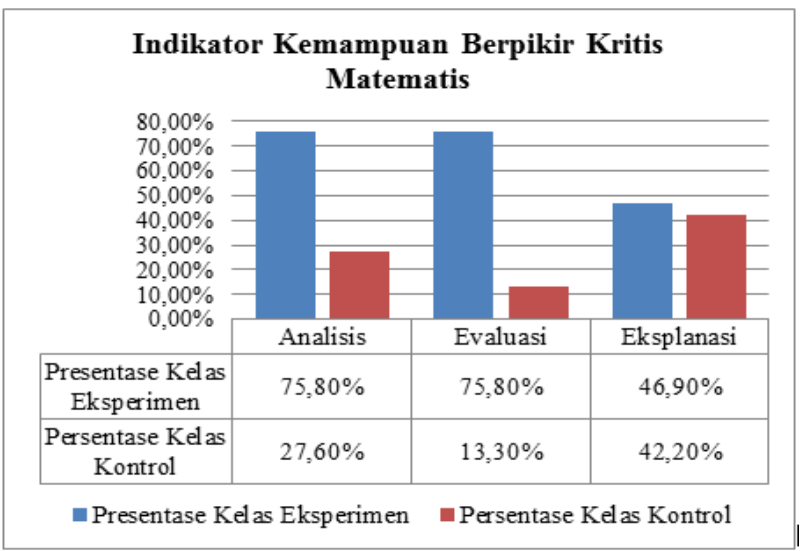

Gambar 1 Diagram Batang Persentase Kemampuan Berpikir Kritis Matematis Siswa Tiap Indikator Kelas Eksperimen Dan Kelas Kontrol

Dari Gambar 1 diketahui bahwa ratarata indikator kemampuan berpikir kritis matematis siswa kelas eksperimen lebih tinggi daripada rata-rata indikator kemampuan berpikir kritis matematis siswa kelas kontrol. Selanjutnya secara keseluruhan rata-rata hasil posttest kemampuan berpikir kritis matematis siswa kelas eksperimen dan kelas kontrol dapat dilihat pada gambar diagram batang 2 sebagai berikut.

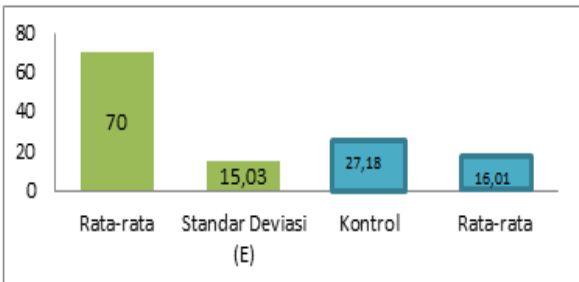

Keterangan:

$$
\begin{aligned}
& =\text { Kelas Eksperimen } \\
& =\text { Kelas Kontrol }
\end{aligned}
$$

Gambar 2 Diagram Batang Nilai Rata-Ratal Posttest Kelas Ekperimen Dan Kelas Kontrol
Dari Gambar 1 dan 2 menunjukan bahwa secara deskriptif rata-rata posttest antara kelas kontrol dan kelas eksperimen berbeda, namun secara inferensial nilai tersebut belum tentu memiliki perbedaan yang signifikan. Untuk melihat perbedaan antara kelas yang menggunakan model pembelajaran Guided Discovery Learning (GDL) dengan kelas yang menggunakan model pembelajaran langsung (kelas kontrol) maka menggunakan uji-t dua sampel independen. Namun sebelumnya dilakukan uji normalitas dan uji homogenitas. Berdasarkan hasil perhitungan, untuk data posttest kelas eksperimen dan kontrol disajikan ada Tabel 1 sebagai berikut:

\section{Tabel 1 Rekapitulasi Perhitungan Uji Normalitas Kelas Eksperimen dan Kontrol}

\begin{tabular}{|c|c|c|c|}
\hline \multicolumn{4}{|c|}{ Eksperimen } \\
\hline $\mathrm{N}$ & & 32 & 32 \\
\hline Normal & Mean & 70.0000 & 27.1875 \\
\hline Parameters ${ }^{a, b}$ & $\begin{array}{l}\text { Std. } \\
\text { Deviation }\end{array}$ & 15.02686 & 16.01096 \\
\hline Most Extreme & Absolute & .153 & .111 \\
\hline Differences & $\begin{array}{l}\text { Positive } \\
\text { Negative }\end{array}$ & $\begin{array}{r}.097 \\
-.153\end{array}$ & $\begin{array}{r}.111 \\
-.093\end{array}$ \\
\hline Test Statistic & & .153 & .111 \\
\hline Asymp. Sig. (2- & & $.054^{c}$ & $.200^{c, d}$ \\
\hline $\begin{array}{l}\text { a. Test distribut } \\
\text { b. Calculated fr } \\
\text { c. Lilliefors Sigr } \\
\text { d. This is a low }\end{array}$ & $\begin{array}{l}\text { is Normal. } \\
\text { data. } \\
\text { ance Corre } \\
\text { ound of the }\end{array}$ & significance. & \\
\hline
\end{tabular}

One-Sample Kolmogorov-Smirnov Test

Dari Tabel 1 diketahui bahwanilai signifikansi SPSS untuk kelas eksperimen dan kelas kontrol berturut-turut adalah 0,054 dan 0,200 yang nilainya lebih besar dari 0,05 yang mengakibatkan Ho diterima sehingga data posttest kelas eksperimen dan kelas kontol berdistribusi normal. 
Selanjutnya dilakukan uji homogenitas untuk data kelas kontrol dan kelas eksperimen, dapat dilihat pada Tabel 2.

Tabel 2 Rekapitulasi Perhitungan Uji Homogenitas Kelas Eksperimen dan Kontrol

Test of Homogeneity of Variances
\begin{tabular}{ccccc} 
Nilai \\
$\begin{array}{c}\text { Levene } \\
\text { Statistic }\end{array}$ & df1 & & df2 & Sig. \\
\hline .568 & 1 & 62 & .454 \\
\hline
\end{tabular}

Dari Tabel 2 diketahui bahwa nilai signifikansi SPSS untuk uji homogenitas dengan uji Levene Statistic adalah 0,454 yang nilainya lebih besar dari 0,05 yang mengakibatkan Ho diterima sehingga data posttest kelas eksperimen dan kelas kontol homogen.

Dikarenakan data berdistribusi normal, dan homogeny maka untuk mengetahui perbedaan penggunaan model pembelajaran GDL dan model pembelajaran langsung peneliti menggunakan uji ANOVA.Adapun rekapitulasi hasil perhitungan perbedaan penggunaan model pembelajaran GDL dan model pembelajaran langsung terhadap kemampuan multi representasi matematis siswa dapat dilihat pada Tabel 2 berikut.

Tabel 3 Rekapitulasi Perhitungan Uji ANOVA

\section{ANOVA}

Nilai

\begin{tabular}{llrrrr}
\hline & $\begin{array}{l}\text { Sum of } \\
\text { Squares }\end{array}$ & df & Mean Square & F & Sig. \\
\hline Between Groups & 29326.563 & 1 & 29326.563 & 121.647 & .000 \\
Within Groups & 14946.875 & 62 & 241.079 & & \\
Total & 44273.438 & 63 & & & \\
\hline
\end{tabular}

Dari Tabel 3 terlihat bahwa nilai signifikansi SPSS adalah 0,00 yang nilainya kurang dari 0,05. Berdasarkan kriteria pengujian maka penggunaan model pembelajaran GDL dan model pembelajaran langsung terhadap kemampuan berpikir kritis matematis siswa dikatakan memiliki perbedaan apabila signifikansi spss $<0,05$ atau Ho ditolak, sebaliknya dikatakan tidak ada perbedaan penggunaan model pembelajaran GDL dan model pembelajaran langsung terhadap kemampuan berpikir kritis matematis siswa apabila signifikansi SPSS > 0,05 atau Ho diterima. Diketahui signifikansi SPSS < 0,05 atau $0,000<0,05$, maka Ho ditolak. Dapat disimpulkan bahwa terdapat perbedaan penggunaan model pembelajaran GDL dan model pembelajaran langsung terhadap kemampuan berpikir kritis matematis siswa pada materi persamaan garis lurus kelas VIII SMP Negeri 6 Singkawang.

Perbedaan kemampuan berpikir kritis matematis antara kelas eksperimen dan kelas kontrol disebabkan pada proses pembelajaran dengan model GDL memiliki tahapan-tahapan yang membuat siswa lebih aktif dan lebih dapat memahami materi. Hal ini disebabkan karena adanya keterkaitan antara model Guided Discovery Learning dan kemampuan berpikir kritis matematis siswa yaitu pada tahap stimulasi dimana masing-masing kelompok diberi kesempatan untuk mengamati LKK, dan tahap pemprosesan data siswa diminta untuk memecahkan masalah dan mengolah data yang terdapat dalam LKK secara kelompok. Hal ini dapat meningkatkan 
berpikir kritis siswa karena siswa memecahkan masalah dan mengembangkan kemampuan bepikirnya menghubungkan materi yang dipelajari dengan pengalaman mereka dalam kehidupan sehari-hari yang membuat mereka berfikir secara beralasan dan reflektif. Guru tidak sekadar memberikan pengetahuan kepada siswa, melainkan memfasilitasi siswa untuk membangun pengetahuannya sendiri sehingga siswa memiliki pemahaman yang lebih mantap terhadap materi persamaan garis lurus.

Hal ini didukung oleh hasil penelitian Widura, dkk (2015) yang menyimpulkan bahwa model Guided Discovery Learning memberikan pengaruh lebih efektif dibandingkan dengan model pembelajaran konvensional terhadap kemampuan berpikir kritis siswa dapat dilihat dari hasil perhitungan uji-t. Nilai rata-rata kemampuan berpikir kritis siswa lebih tinggi pada kelas eksperimen yaitu 79,07 sedangkan nilai rata-rata kelas kontrol 68,2 hal ini membuktikan bahwa penerapan model pembelajaran Guided Discovery Learning berpengaruh signifikan terhadap kemampuan berpikir kritis siswa.

Selanjutnya untuk melihat seberapa besar pengaruh model pembelajaran GDL terhadap kemampuan berpikir kritis matematis siswa, maka digunakan rumus Effect Size. Adapun hasil perhitungan Effect Size dapat dilihat pada Tabel 3 sebagai berikut.

Tabel 4 Rekapitulasi Hasil Uji Efffect Size

\begin{tabular}{ccccc}
\hline Kelas & Nilai Rata-rata & $\begin{array}{c}\text { Standar Deviasi } \\
\text { Kelas Kontrol }\end{array}$ & ES & Kriteria \\
\hline Eksperimen & 70 & 16,01 & 2,67 & $\begin{array}{c}\text { Pengaruhnya } \\
\text { Tinggi }\end{array}$ \\
Kontrol & 27,2 & & & . \\
\hline
\end{tabular}

Dari Tabel 4 dapat dilihat bahwa hasil perhitungan Effect Size = 2,67 dengan kriteria tinggi karena 2,67 berada pada $\mathrm{ES} \geq 0,8$. Ini berarti model pembelajaran GDL memberikan pengaruh terhadap kemampuan berpikir kritis matematis siswa yaitu sebesar 2,67 yang masuk pada kriteria tinggi.

\section{Aktivitas Belajar Siswa}

Lembar observasi digunakan untuk mengetahui aktivitas siswa selama mengikuti pembelajaran dengan menggunakan model pembelajaran GDL. Pengamatan dilakukan selama dua kali pertemuan dengan 3 orang pengamat, persentase hasil pengamatan aktivitas siswa selama dua pertemuan disajikan dalam tabel 5 sebagai berikut.

Tabel 5 Rekapitulasi Persentase Pengamatan Aktivitas Siswa Peremuan Pertama dan Kedua

\begin{tabular}{ccccc}
\hline No & Kategori Pengamatan & Pertemuan 1 & Pertemuan 2 & Rata-rata \\
\hline 1 & Visual Activities & $89,93 \%$ & $89,24 \%$ & \\
2 & Oral Activities & $89,58 \%$ & $88,54 \%$ & \\
3 & Listening Activities & $87,50 \%$ & $87,15 \%$ & $\mathbf{8 8 , 2 5} \%$ \\
4 & Writing Activities & $89,58 \%$ & $89,58 \%$ & \\
5 & Drawing Activities & $91,67 \%$ & $90.63 \%$ & \\
6 & Mental Activities & $89,58 \%$ & $76,04 \%$ & \\
& Jumlah & $537,87 \%$ & $521,18 \%$ & \\
& Rata-rata & $89,64 \%$ & $86,86 \%$ & \\
& Kriteria & Sangat Aktif & \\
\hline
\end{tabular}

Dari Tabel 5 dapat dilihat bahwa persentase rata-rata aktivitas pada pertemuan pertama dan kedua data persentase aktivitas siswa diperoleh rata-rata dari lima kategori pengamatan, dua kali pertemuan dan tiga orang pengamat yaitu sebesar $88,25 \%$. Hal ini menunjukkan bahwa aktivitas siswa selama pembelajaran dengan model GDL berlangsung berada pada kategori sangat aktif. Berdasarkan analisis data hasil pengamatan aktivitas siswa diperoleh bahwa aktivitas siswa setiap indikator dalam kategori aktif. Hal ini disebabkan 
pembelajaran menggunakan model pembelajaran GDL mampu membuat siswa aktif bertanya kepada kelompok yang melakukan presentasi (Mental Activities). Hal ini menunjukkan bahwa siswa sudah mulai mengevaluasi gagasangagasan yang dimiliki (tahap generalisasi).

Dari pembahasan tersebut dapat disimpulkan bahwa sebagian besar tahapan model pembelajaraan Guided Discovery Learning dapat meningkatkan kegiatan yang aktif dalam beberapa kategori aktivitas. Berdasarkan hasil analisis yang dilakukan oleh Tasrifuddin (2016) analisis data yang diperoleh dari hasil tes hasil belajar siswa dapat ditarik kesimpulan: (1) Terdapat perbedaan antara hasil belajar siswa kelas XI IPA di SMA Negeri 2 Sungai Raya yang diajar menggunakan model Guided Discovery Learning dengan hasil belajar siswa yang diajar menggunakan model pembelajaran konvensional pada materi laju reaksi yang diperoleh dari uji U-Mann Whitney yang menghasilkan Asymp. Sig. (2-tailed) sebesar 0,015; (2). Terdapat perbedaan antara aktivitas belajar siswa kelas XI IPA di SMA Negeri 2 Sungai Raya yang diajar menggunakan model Guided Discovery Learning dengan aktivitas belajar siswa yang diajar menggunakan model pembelajaran konvensional pada materi laju reaksi yang diperoleh dari uji U-Mann Whitney yang menghasilkan Asymp. Sig. (2-tailed) sebesar 0,000; (3) Pembelajaran menggunakan model Guided Discovery Learning pada materi laju reaksi memberikan pengaruh sebesar 24,54\% terhadap hasil belajar siswa kelas XI IPA SMA Negeri 2 Sungai Raya.

\section{Motivasi Belajar Siswa}

Angket motivasi belajar siswa dalam penelitian ini merupakan angket yang hanya diberikan kepada siswa kelas eksperimen untuk mengetahui seberapa besar motivasi siswa dengan diterapkan model pembelajaran GDL. Angket motivasi belajar tersebut merupakan angket tertutup dan siswa hanya memilih satu jawaban dari 5 pilihan yang diberikan (sangat setuju, setuju, ragu-ragu, tidak setuju dan sangat tidak setuju) yang telah disediakan. Angket motivasi yang digunakan berupa pernyataan positif dan pernyataan negatif yang berjumlah 20 pernyataan dan terdiri dari 5 indikator motivasi belajar.

Hasil perhitungan rata-rata angket motivasi belajar siswa pada pernyataan positif pada kelas eksperimen dapat dilihat pada Tabel 6 sebagai berikut.

\section{Tabel 6 Rekapitulasi Hasil Angket Motivasi} Siswa untuk Pernyataan Positif

\begin{tabular}{|c|c|c|c|c|c|c|c|c|}
\hline \multirow{2}{*}{ Indikator } & \multicolumn{5}{|c|}{ Jumlah siswa pada pilihan } & \multirow{2}{*}{$\begin{array}{l}\text { Jumlah } \\
\text { skor }\end{array}$} & \multirow{2}{*}{$\begin{array}{l}\text { Rata- } \\
\text { rata }\end{array}$} & \multirow{2}{*}{ Kriteri } \\
\hline & SS & S & RR & TS & STS & & & \\
\hline $\begin{array}{l}\text { Adanya dorongan dan } \\
\text { kebutuhan dalam belajar }\end{array}$ & 31 & 23 & 8 & 2 & 0 & 275 & 4,29 & Tinggi \\
\hline $\begin{array}{l}\text { Menunjukan perhatian } \\
\text { dan minat terhadap tugas- } \\
\text { tugas yang diberikan }\end{array}$ & 38 & 55 & 2 & 0 & 1 & 417 & 4,33 & $\begin{array}{l}\text { Sangat } \\
\text { Tinggi }\end{array}$ \\
\hline Tekun menghadapi tugas & 20 & 26 & 14 & 3 & 1 & 253 & 3,95 & Tinggi \\
\hline $\begin{array}{l}\text { Ulet menghadapi } \\
\text { kesulitan }\end{array}$ & 34 & 12 & 6 & 11 & 1 & 259 & 4,05 & Tinggi \\
\hline $\begin{array}{l}\text { Adanya hasrat dan } \\
\text { keinginan berhasil }\end{array}$ & 43 & 46 & 7 & 0 & 0 & 420 & 4,37 & $\begin{array}{l}\text { Sangat } \\
\text { Tinggi }\end{array}$ \\
\hline \multicolumn{6}{|c|}{ Rata-Rata Keseluruhan } & 1624 & 4,20 & Tinggi \\
\hline
\end{tabular}

Dari Tabel 6 dapat dilihat bahwa rata-rata motivasi belajar siswa untuk pernyataan positif dari kelima indikator tersebut secara keseluruhan memiliki kriteria tinggi dengan nilai rata-rata keseluruhan 4,20. Selanjutnya untuk hasil perhitungan rata-rata angket motivasi belajar siswa pernyataan negatif pada kelas eksperimen dapat dilihat pada Tabel 7 berikut. 
Tabel 7 Rekapitulasi Hasil Angket Motivasi Siswa untuk Pernyataan Negatif

\begin{tabular}{|c|c|c|c|c|c|c|c|c|}
\hline \multirow{2}{*}{ Indikator } & \multicolumn{5}{|c|}{ Pilihan } & \multirow{2}{*}{$\begin{array}{l}\text { Jumlah } \\
\text { skor }\end{array}$} & \multirow{2}{*}{$\begin{array}{c}\text { Rata- } \\
\text { rata }\end{array}$} & \multirow{2}{*}{ Kriteria } \\
\hline & SS & $\mathrm{S}$ & RR & TS & STS & & & \\
\hline $\begin{array}{l}\text { Adanya dorongan dan kebutuhan } \\
\text { dalam belajar }\end{array}$ & 3 & 4 & 1 & 24 & 32 & 270 & 4,2 & Tingg \\
\hline $\begin{array}{l}\text { Menunjukan perhatian dan minat } \\
\text { terhadap tugas-tugas yang diberikan }\end{array}$ & 2 & 4 & 16 & 12 & 30 & 256 & 4 & Tingg \\
\hline Tekun menghadapi tugas & 2 & 2 & 2 & 9 & 6 & 78 & 3,71 & Tingg \\
\hline Ulet menghadapi kesulitan & 2 & 5 & 10 & 30 & 17 & 247 & 3,85 & Tingg \\
\hline Adanya hasrat dan keinginan berhasil & 1 & 2 & 1 & 10 & 7 & 83 & 3,95 & Ting \\
\hline \multicolumn{6}{|c|}{ Rata-Rata Keseluruhan } & 934 & 3,94 & Tingg \\
\hline
\end{tabular}

Dari Tabel 7 dapat dilihat bahwa ratarata motivasi belajar siswa untuk pernyataan negatif dari kelima indikator tersebut secara keseluruhan memiliki kriteria tinggi dengan nilai rata-rata keseluruhan 3,94. Secara keseluruhan rata-rata motivasi belajar siswa baik dari pernyataan positif dan pernyataan negatif dapat dilihat pada Tabel 8 berikut ini.

Tabel 8 Rekapitulasi Hasil Angket Motivasi Siswa untuk Seluruh Indikator

\begin{tabular}{lcc}
\hline Kategori & Rata-rata & Kriteria \\
\hline $\begin{array}{l}\text { Adanya dorongan dan kebutuhan dalam } \\
\text { belajar }\end{array}$ & 4,24 & Tinggi \\
$\begin{array}{l}\text { Menunjukan perhatian dan minat } \\
\text { terhadap tugas-tugas yang diberikan }\end{array}$ & 4,16 & Tinggi \\
Tekun menghadapi tugas & 3,83 & Tinggi \\
Ulet menghadapi kesulitan & 3,95 & Tinggi \\
Adanya hasrat dan keinginan berhasil & 4,16 & Tinggi \\
Rata-rata Keseluruhan & $\mathbf{4 , 0 7}$ & Tinggi \\
\end{tabular}

Dari Tabel 8 dapat dilihat bahwa ratarata motivasi belajar siswa untuk pernyataan positif dan negatif pada semua indikator berada pada kriteria tinggi dengan jumlah 32 siswa menghasilkan rata-rata keseluruhan siswa adalah 4,07 dengan kriteria tinggi karena berada pada kisaran $3,4 \leq(X) \leq 4,2$.

Tingginya motivasi belajar siswa kelas ekperimen pada penelitian ini dikarenakan pada model pembelajaran GDL, siswa tidak langsung diberikan hasil akhir dari penyelesaian, melainkan siswa dilatih untuk belajar menyelesaikan masalah dengan cara mereka sendiri melalui diskusi bersama teman sekelompoknya dengan bantuan guru sehingga menimbulkan keingintahuan mereka untuk bisa menyelesaikan masalah yang secara tidak langsung memotivasi keinginan siswa untuk belajar, misalnya pada salah satu tahapan Seperti halnya ada tahap pengumpulan data siswa diminta untuk mengumpulkan informasi dari berbagai sumber seperti buku secara berkelompok, sehingga membuat siswa ulet dalam menyelesaikan tugas.

Hal ini menunjukan tingginya mootivasi belajar siswa pada model Guided Discovery Learning. Dan sejalan dengan hasil penelitian Istiqomah (2013) yang menunjukkan bahwa motivasi dan hasil belajar siswa meningkat setelah diterapkan model Guided Discovery Learning pada siklus I $(52,63 \%)$ dan pada siklus II $(84,21 \%)$ meningkat hingga $31,58 \%$.

\section{SIMPULAN (PENUTUP)}

Berdasarkan hasil pengelolaan data hasil penelitian dan pembahasan secara umum dapat disimpulkan bahwa model pembelajaran Guided Discovery Learning dapat memberikan pengaruh yang tinggi terhadap kemampuan berpikir kritis matematis pada materi persamaan garis lurus kelas VIII SMP Negeri 6 Singkawang. Sesuai dengan sub-sub rumusan masalah penelitian, secara khusus dapat disimpulkan hal-hal sebagai berikut.

1. Terdapat perbedaan kemampuan berpikir kritis matematis antara siswa yang mendapatkan model pembelajaran Guided Discovery Learning dengan siswa yang mendapatkan pembelajaran konvensional pada materi persamaan garis lurus kelas VIII SMP Negeri 6 Singkawang. 
2. Model pembelajaran Guided Discovery Learning memberikan pengaruh yang tinggi terhadap kemampuan berpikir kritis matematis siswa pada materi persamaan garis lurus kelas VIII SMP Negeri 6 Singkawang.

3. Aktivitas belajar siswa tergolong aktif setelah diterapkan model Guided Discovery Learning (GDL) pada materi persamaan garis lurus kelas VIII SMPN 6 Singkawang terhadap kemampuan berpikir kritis matematis.

4. Motivasi belajar siswa tergolong tinggi dengan diterapkannya model Guided Discovery Learning (GDL) pada materi persamaan garis lurus kelas VIII SMPN 6 Singkawang terhadap kemampuan berpikir kritis matematis.

\section{UCAPAN TERIMAKASIH}

Penulis mengucapkan terima kasih kepada seluruh dosen Pendidikan Matematika STKIP Singkawang, kepada Ketua STKIP Singkawang Drs. Andi Mrsidi, M.Si yang telah memberikan arahan dan bimbingan dalam penulisan artikel hasil penelitian ini.

\section{DAFTAR PUSTAKA}

Ennis, R.H. 1991. Critical Thingking: A Streamlined Conception. Teacher Philashopy.

Haris, F dkk. 2015. Pengaruh Model Guided Discovery Learning Terhadap Kemampuan Berpikir Kritis Siswa Kelas X SMA Negeri Karang Pandan Tahun Ajaran 2013/2014. Jurnal FKIP UNS.

Istiqomah, F., Sarengat, S., \& Muncarno, M. 2013. Penerapanan Model Guided Discovery Learning untuk
Meningkatkan Motivasi dan Hasil Belajar Siswa. Jurnal Pedagogi, 1(8).

Prihandoko, A. Cahya. 2006. Pemahaman dan Penyajian Konsep Matematika Secara Benar dan Menarik. Jakarta: Direktorat Jendral Pendidikan Tinggi

Sari, M, dkk. 2016. Analisis Kemampuan Berpikir Kritis Kelas VIII D SMP Negeri 1 Gabut. Jurnal Universitas Negeri Malang.

Somakim . 2011. Peningkatan Kemampuan Berpikir Kritis Matematis Siswa Sekolah Menengah dengan Penggunaan Pendidikan Matematika Realistik. Jurnal Forum MIPA, 14(1).

Sumarmo, U. 2002. Alternatif Pembelajaran Matematika Untuk Mendukung Pelaksanaan Kurikulum Berbasis Kompetensi. Makalah Pada Seminar Tingkat Nasional FPMIPA UPI. Bandung

Tasrifuddin. 2016. Pengaruh Model Guided Discovery Learning Terhadap Aktivitas Dan Hasil Belajar Siswa SMAN 2 Sungai Raya Materi Laju Reaksi. Jurnal Pendidikan Matematika Universitas Tanjungpura

Wahyuni, R., Mariyam, M., \& Sartika, D. 2018. Efektivitas Model Pembelajaran Creative Problem Solving (CPS) Dalam Meningkatkan Kemampuan Berfikir Kritis Matematis Siswa Pada Materi Persamaan Garis Lurus. JPMI (Jurnal Pendidikan Matematika Indonesia), 3(1):26-31.

Widura, HS dkk. 2015 Pengaruh Model Guided Discovery Learning Terhadap Kemampuan Berpikir Kritis Siswa Kelas X SMA Negeri 8 Surakarta Tahun Ajaran 2014/2015. Jurnal Universitas Sebelas Maret. 